\title{
A História do Crescimento Econômico Brasileiro e a Restrição Externa
}

\section{The History of Brazilian Economic Growth and the Balance of Payments Constraint}

Veridiana Ramos Carvalho* Ana Carolina Giuberti**

\begin{abstract}
Resumo: O trabalho estuda os efeitos das políticas econômicas adotadas no período de 1930-2007 sobre o comportamento das elasticidades-renda das demandas por importação e exportação para a economia brasileira, dentro do contexto da teoria do crescimento sob restrição externa. Com base em um modelo em primeiras diferenças estimado por mínimos quadrados ordinários, o estudo identifica os períodos históricos em que houve quebra nos parâmetros das funções de exportação e importação e os relaciona com as políticas seguidas. Os resultados encontrados permitem concluir que, ainda que o crescimento de um país seja restrito pela estrutura do seu comércio externo, essa estrutura pode ser modificada por meio de políticas governamentais.
\end{abstract}

Palavras-chave: Política econômica. Crescimento. Restrição externa. Elasticidade-renda.

Abstract: The paper studies the effects of economic policies adopted in the period 1930-2007 on the behavior of the income elasticities of demand for imports and exports of the Brazilian economy, under the balance-of-paymentsconstrained growth model. Based on a model in first differences estimated by least squares, the study identifies the historical periods when there were breaks in these parameters and related then to policies followed. The results indicate that although the growth of a country is restricted by the structure of its foreign trade, this structure can be modified by governmental policies.

Keywords: Economic policy. Growth. Balance-of-payments constraint. Income elasticity.

JEL Classification: E12; N16; O11.

Mestra e doutoranda pela FEA-USP.E-mail: vrc@usp.br

** Professora do Departamento de Economia da UFES. Mestra e doutoranda pela FEA-USP.

E-mail: anagiuberti@yahoo.com.br 


\section{Introdução}

De acordo com a teoria do crescimento sob restrição externa, conforme definida por Thirwall (1979) e algumas de suas variações, o crescimento de longo prazo dos países está restrito à necessidade de equilíbrio no balanço de pagamentos. Embora no curto prazo um país possa apresentar déficits nas suas contas externas, essa situação não pode ser mantida indefinidamente. No longo prazo, o balanço de pagamentos deve estar em equilíbrio.

Diversos estudos sobre a economia brasileira confirmaram que a restrição do balanço de pagamentos foi fundamental para a definição do produto da economia brasileira de longo prazo. Entre esses estudos, podem ser citados Thirlwall e Hussain (1982), Holland, Vieira e Canuto (2004), Lopez e Cruz (2000), Bértola, Higachi e Porcile (2002), Jayme Jr. (2003), Ferreira (2001), Carvalho, Lima e Santos (2005), entre outros.

Entretanto, a restrição externa é objeto de política e deve se modificar com ela, conforme diz Thirlwall (2002, p. 78):

A única solução certa para aumentar a taxa de crescimento de longo prazo compativel com o equilíbrio do Balanço de Pagamentos é modificar a razão de elasticidades. Estamos, portanto, de volta às idéias de Raul Prebisch e à questão da política industrial mais apropriada e o papel da proteção. (THIRLWALL, 2002, p. 78).

Ao refazer a história econômica do Brasil, parece evidente que diversificar a estrutura produtiva, objetivando modificar a posição do país na divisão internacional do trabalho e diminuir a transferência de renda ao exterior foi um objetivo fundamental de política econômica entre as décadas de 1930 e 1970, confirmando, assim, a inspiração estruturalista. Dessa forma, ao longo dos processos político-econômicos que ocorreram no Brasil nesse período, é bastante provável que os parâmetros estruturais do modelo de restrição externa, as elasticidadesrenda das importações e exportações, tenham se alterado em razão da própria política adotada. Do mesmo modo, as políticas adotadas nas décadas seguintes (1980-2007) também podem ter afetado essas elasticidades, ainda que não tivessem por objetivo alterar diretamente a estrutura produtiva brasileira - dado que esse projeto foi interrompido na década de 1980 e modificado com as reformas liberalizantes dos anos 1990, deixando para os anos 2000 a tarefa de reconstruir um projeto de desenvolvimento.

Diante deste debate, o principal objetivo do trabalho é relacionar a trajetória de crescimento da economia brasileira durante e após a 
industrialização, ou seja, entre 1930-2007, à restrição externa que parece permear a história econômica do período. Entretanto, é importante ressaltar que o país não ficou passivo à restrição do balanço de pagamentos, elaborando políticas que permitissem relaxar essa restrição. São os resultados dessas políticas, o comportamento do crescimento econômico e da restrição externa que serão estudados neste trabalho, a partir da análise empírica das quebras nas elasticidades-renda de importação e exportação, a sua relação com a política econômica do período e as variações da taxa de crescimento.

Note-se que a escolha de um período de estudo amplo (1930-2007), infelizmente, inviabilizou análises mais profundas e a recuperação mais detalhada dos debates de cada subperíodo. Entretanto, isso foi feito em prol de uma análise mais ampla da relação entre políticas públicas, restrição externa e crescimento brasileiro, que se perderia caso a análise se concentrasse em um ou dois subperíodos, uma vez que as especificidades se sobreporiam a essa análise mais ampla que este artigo se propõe a fazer.

Para elaborar este estudo, será feita, na próxima seção, uma revisão estilizada dos períodos da história econômica brasileira analisados neste trabalho. A seção 3 faz uma revisão bibliográfica dos modelos de restrição externa, enquanto a seção 4 explica a metodologia de teste adotada neste trabalho. A seção 5 apresenta os principais resultados, e a seção 6 interpreta os resultados, tendo em vista a política adotada (revisada na seção 2) e o crescimento do período. A seção 7 tece algumas considerações finais.

\section{Uma Breve e Estilizada Revisão da História Econômica Brasileira: 1930-2007}

Esta seção faz uma revisão bastante estilizada da História Econômica Brasileira no período 1930-2007, buscando delinear períodos em que ocorreram processos de política econômica que afetaram a restrição externa. O resultado dessa abordagem foi a divisão do período estudado em dez subperíodos, ${ }^{1}$ sendo nove deles abrangendo o período 1937-2007, analisados pela metodologia econométrica apresentada na seção 4. Ainda assim, a revisão parte do período 1930-1937 que, embora não faça parte dos nove subperíodos analisados, é a base inicial dos ciclos políticos e econômicos subsequentes.

1 A divisão dos períodos foi construída com base nas transformações de política que possivelmente alteraram a restrição externa e foi influenciada pela análise da economia brasileira feita em Abreu (1990a). 
Até 1930, o modelo de desenvolvimento brasileiro pode ser classificado como "para fora", como colocam Furtado (1959) e Tavares (2000). A principal característica desse modelo é que o setor exportador, cuja demanda era determinada exogenamente, representava o centro dinâmico da economia, sendo exclusivamente responsável pelo crescimento do produto.

No bojo do modelo exportador, surgiram indústrias tradicionais, basicamente de alimentos e têxteis, voltadas para o mercado interno, que tinham como característica um baixo nível de produtividade quando comparadas ao setor exportador. A característica mais importante desse modelo é sua natureza dual:

O setor exportador era um setor bem definido da economia, geralmente de alta rentabilidade econômica, especializado em um ou poucos produtos... Já o setor interno, de baixa produtividade, era basicamente subsistência, e somente satisfazia parte das necessidades de alimentação, vestuário e habitação. (TAVARES, 2000, p. 221-222).

Esse esquema dual de divisão de trabalho e a grande desigualdade de renda interna geraram uma "tremenda disparidade entre a estrutura de produção e a composição da demanda interna, cujo ajuste se dava por intermédio do mecanismo de comércio exterior" (TAVARES, 2000, p. 222).

A grande depressão dos anos 1930 causou uma forte queda na receita de exportação, o que provocou uma ruptura com o modelo exportador. No Brasil, uma forte depreciação cambial pós-crise de 1930, a necessária restrição e o controle das importações, a manutenção da renda interna através da política de compra e a queima do café, e a existência de uma capacidade ociosa foram as responsáveis pelo estímulo à primeira onda de substituição de importações e o consequente deslocamento do centro dinâmico das exportações para o investimento para substituir importações. Posteriormente, o processo ganha dinâmica própria.

Assim, a partir da crise de 1930, a economia brasileira passa a viver um novo modelo de desenvolvimento, classificado pela literatura como Processo de Substituição de Importações (PSI). O investimento na indústria para substituir as importações passa a ser o elemento dinâmico da renda interna.

Tavares (2000, p. 230, grifo nosso) define o PSI como um “[...] processo de desenvolvimento interno que tem lugar e se orienta sob o impulso de restrições externas e se manifesta, primordialmente, através de uma ampliação e diversificação da capacidade produtiva industrial". Assim, essa é a natureza que assume o processo de desenvolvimento econômico a partir de então. 


\subsection{Período 1937-1944}

A partir do Estado Novo, em 1937, novamente em resposta a um choque externo (recessão norte-americana), inicia-se mais um ciclo do PSI. O governo assumiu seu papel de liderança no desenvolvimento, deixando de ser apenas um Estado Normativo, tornando-se também um provedor de bens e serviços. A decisão de iniciar a Companhia Siderúrgica Nacional, a partir de 1940, foi um marco dessa transformação.

Além disso, a política de câmbio desvalorizado, que passa a ser monopólio do governo central, e um sistema de controle cambial e de tarifas, após 1937, fizeram da política cambial um forte instrumento de política econômica e de financiadora do desenvolvimento.

A ordem natural de um processo de substituição de importações é que primeiro se substituam produtos de consumo terminados, com menor componente tecnológico e baseados na demanda interna existente. No entanto, é preciso que a substituição também avance para os setores de intermediários e bens de capital, para evitar que uma excessiva rigidez na pauta de importações comprometa o aprofundamento do processo. Ainda segundo Tavares (2000), essa foi uma característica importante do PSI brasileiro, ou seja, o PSI se aprofundou em setores de bens intermediários e de capital já nas etapas iniciais, desde 1937. Um exemplo disso foi a implantação da Companhia Siderúrgica Nacional, que avançou na produção de bens intermediários.

Com a proximidade do final da guerra, o governo norte-americano passou a apoiar uma solução mais liberal para o Brasil, o que envolveria políticas econômicas mais alinhadas àquele governo. O período encerrou-se com a deposição de Getúlio Vargas, em 1945.

\subsection{Período 1945-1954}

Esse período após a Segunda Guerra Mundial abrange dois governos: o Governo Dutra e a segunda era Vargas e representaram um aprofundamento importante do PSI, com a criação de importantes instrumentos de política pública.

Neste período, a carência de divisas no pós-guerra, sem o abandono do programa de desenvolvimento, fez com que o governo adotasse as Licenças de Importação. Ou seja, as importações necessárias para investimentos industriais eram liberadas a uma taxa de câmbio bastante favorável, enquanto as importações de produtos que concorriam com a produção interna eram limitadas.

Se, por um lado, a valorização cambial foi bastante prejudicial às exportações não tradicionais, por outro, a disponibilidade de divisas 
provenientes do café aumentou, gerando divisas que possibilitaram o avanço do PSI.

Já a partir de 1952 foi adotada a taxa de câmbio múltipla, que permitiu uma política industrial mais direta, com maior controle do Estado sobre os setores que seriam incentivados e penalizados.

Dessa forma, foi um período de forte aprofundamento do PSI nos setores de bens de consumo leves, ou seja, alimentos e têxteis, e nos setores de ferroligas, aços planos, aços longos, cimento, papel e química que tiveram um crescimento expressivo (IPEA, 1998). As importações de bens de capital para sustentar esse aprofundamento do PSI aumentaram e foram propiciadas pela discriminação de tarifas.

\subsection{Período 1955-1961}

A partir do governo Kubitschek (1955), o PSI se aprofundou nos setores de química, máquinas e equipamentos elétricos, plásticos, equipamentos de transporte, metalurgia, e iniciou a substituição nos setores de bens de consumo duráveis, especialmente automóveis. O governo participou diretamente da industrialização no período, através de um extenso plano de investimentos públicos em infraestrutura e bens intermediários: o Plano de Metas. Um aspecto fundamental do aprofundamento do PSI que ocorreu nesse período foi o aumento significativo da participação do capital externo, principalmente nos setores de duráveis. Isso foi possibilitado pela Instrução 113 da SUMOC, que permitia ao capital estrangeiro importar equipamentos sem cobertura cambial. Assim formou-se o tripé do desenvolvimento brasileiro: Estado, Capital Estrangeiro e Capital Nacional. Neste período, além do Estado contar com todos os instrumentos de políticas públicas, como taxas de câmbio múltiplas entre outras, chegou-se em um estágio do PSI em que foi possível mapear seus gargalos e, com a participação do capital estrangeiro, elaborar um minucioso Plano de Investimentos que objetivava fazer o país crescer "Cinquenta anos em cinco" (Plano de Metas).

\subsection{Período 1962-1967}

No início dos anos 1960, a economia brasileira presenciou uma diminuição da taxa de crescimento do PIB e uma queda da taxa de investimento, o que, aliado a um valor significativamente baixo do coeficiente de importação, levou diversos economistas, como Tavares, a diagnosticarem o fim do crescimento via PSI.

Era necessário aprofundar o processo nos setores de bens de capital, intermediários e infraestrutura urbana. No entanto, a ausência de mecanismos de financiamento do setor privado e público inviabilizava 
os investimentos que necessitavam de cada vez mais recursos financeiros, à medida que a industrialização se aprofundava.

Com o golpe militar de 1964, o ambiente não democrático facilitou a introdução de profundas reformas, estruturadas no PAEG (19641968). O plano partiu do diagnóstico oficial de que a crise era fruto do desequilíbrio externo e do descontrole da inflação, ambos relacionados às finanças públicas, e de que a inflação também era causada pela expansão do crédito via Banco do Brasil e dos aumentos salariais acima da produtividade. As medidas propostas visavam, portanto, a enfrentar esses três pontos, com controle do déficit público, contenção do crédito e compressão salarial. Além disso, foram realizadas as reformas no setor financeiro - com a criação do BACEN, do Conselho Monetário Nacional, do Sistema Financeiro de Habitação, bancos de investimentos, introdução da correção monetária, a criação da estrutura de intermediação bancária com a permissão para os bancos de tomar empréstimos no exterior e emprestar a juros no Brasil (Resolução n. 63 de 1967) - e a reforma tributária, base do sistema atualmente em vigor, que permitiu a recapitalização do Estado. Assim, as reformas do PAEG reconstruíram os mecanismos de financiamento público e privado e dotaram o Estado de maiores instrumentos de intervenção na economia.

\subsection{Período 1968-1973}

Logo, pode-se dizer que a partir de 1968, o Processo de Substituição de Importações voltou a se aprofundar e a promover o crescimento do país, ainda sob forte influência estruturalista. Entre 1968-1973, período do chamado Milagre Econômico, o produto cresceu em média 10\% a.a., liderado pelo setor de bens duráveis.

Foram o crescimento mundial no período e os termos de trocas favoráveis que possibilitaram ao país conduzir com êxito um dos primeiros programas ${ }^{2}$ voltados para exportação com a criação do Concex (1967), que já estava em estágio embrionário desde 1964. No caso das importações, promoveu-se uma redução de tarifas, mas que permaneceram em patamares ainda altos.

2 Antes desse período, o incentivo explícito às exportaçães não estava posto como objetivo de política. Pelo contrário, em muitos casos, as exportações foram prejudicadas em nome do processo de substituição de importação, com a manutenção de uma taxa de câmbio apreciada e a imposição de licenças para exportação de outros produtos que não o café. Essa forma como as exportações foram tratadas pelos sucessivos governos, em particular no período 1947-1962, levou Leff (1967, p. 289) a afirmar que a política governamental implicitamente abordou a questão das exportações sobre a óptica do excedente exportável. De acordo com essa visão, um país exporta apenas o excedente da sua produção, após as necessidades internas terem sido adequadamente atendidas. O resultado, segundo o autor, foi a estagnação das exportações brasileiras de outros produtos que não o café durante o período citado. 
A posição do Governo de concessor de crédito e principal demandante da indústria tornava possível uma forte influência na economia.

\subsection{Período 1974-1982}

O choque do petróleo, no final de 1973, encerrou a fase do Milagre Econômico brasileiro e colocou o novo governo, que assumiu em 1974, diante de uma difícil escolha, dada a mudança no cenário internacional. Uma opção seria o ajustamento, provocando uma desvalorização cambial para ajustar o setor externo e adotando medidas de contenção de demanda, o que provocaria uma inevitável queda no crescimento do produto. Uma segunda opção seria o financiamento do déficit em transações correntes, enquanto se faria o ajustamento da oferta interna. O governo optou pela segunda estratégia, lançando o II PND. Segundo Plano Nacional de Desenvolvimento. O fato é que se iniciou uma fase de aprofundamento do PSI em setores de intermediários, comandado por estatais, e bens de capitais, comandado pelo setor privado com incentivos do governo. Além do aprofundamento do PSI, houve um claro esforço no sentido de incentivar as exportações de produtos não tradicionais, ou seja, "[...] grande ênfase nas indústrias básicas, e o da eletrônica pesada, assim como no campo de insumos básicos, a fim de substituir importações e, se possível, abrir novas frentes de exportação" (CARNEIRO, 1990, p. 310). Assim, nesse período, houve uma forte expansão nos setores de produção e prospecção de petróleo, energia elétrica, alumínio, petroquímica, bens de capital, papel e celulose, metais não ferrosos, fertilizantes e aço. Segundo Carneiro (1990, p. 313), “[...] as conclusões têm sido favoráveis no sentido de que objetivos gerais de reestruturação da oferta foram atingidos". No entanto, o aumento do endividamento externo e público, aliado à reversão da situação de liquidez internacional que culminou no aumento abrupto da taxa de juros internacional em 1979, contribuíram para uma forte e profunda crise do balanço de pagamentos na década de 1980.

\subsection{Período 1982-1989}

Na década de 1980, o PSI brasileiro entra em crise, juntamente com as profundas transformações do cenário internacional que se iniciaram na década de 1970 e culminaram em 1979 com um aumento abrupto da taxa de juros internacional. Nesta década, posteriormente denominada a década perdida, o país viveu um aprofundamento dos desequilíbrios macroeconômicos.

A deterioração fiscal e externa, a inflação altíssima e o fracasso de uma sequência de planos de estabilização, juntamente com a deterio- 
ração das poupanças externa e pública, provocaram uma redução abrupta na taxa de investimento. A percepção era de que a trajetória de crescimento sustentável que o país viveu nas décadas anteriores tinha se perdido definitivamente, ao menos nos marcos do modelo vigente.

\subsection{Período 1990-1999}

No início da década de 1990, o cenário internacional foi marcado por um movimento cada vez mais intenso do fluxo de capitais, de informações e de transformação tecnológica. No cenário interno, havia uma percepção generalizada de que o profundo desequilíbrio macroeconômico e o marco institucional de um modelo baseado no PSI não propiciariam a internalização dessas transformações no cenário internacional.

Assim, foi a partir da crise dos anos 1980 e, possivelmente, como consequência dela, que toda uma estratégia de desenvolvimento, que tinha inspirado a política econômica desde a década de 1930, deixa definitivamente de ser predominante e a estratégia neoliberal ganha toda a força na influência da política econômica. As reformas dos anos 1990 redefiniram o papel do Estado e fortaleceram o mercado na definição da alocação de recursos, assim como iniciaram um profundo processo de abertura da economia, tanto para os fluxos comerciais como para os fluxos de capitais. Logo, os três principais pilares das reformas dos anos 1990 foram: a abertura econômica, a privatização e a desregulamentação econômica. Além disso, na condução da política econômica, foi dada prioridade total ao processo de estabilização, enquanto houve um intenso uso da poupança externa, ao menos enquanto isso foi possível.

\subsection{Período 2000-2007}

Se, por um lado, a estratégia adotada nos anos 1990 pode ser considerada bem sucedida na estabilização da economia, por outro, foi um fracasso em termos de crescimento econômico: o crescimento da década de $1990(1,9 \%)$ foi mais baixo que o crescimento $\left(3,0 \%^{3}\right)$ da década perdida (1980).

Assim, a nova década inicia-se com uma baixa aprovação das reformas liberalizantes que contribuiram na eleição, em 2004, do candidato de oposição. Ciente de que a história não dá passos para trás e de que a economia do Milagre Economico não voltaria mais, essa década tinha o encargo de reconstruir uma estratégia de desenvolvimento.

3 Fonte: IBGE. Disponível em: <www.ipeadata.gov.br >. 


\section{Modelos de Crescimento com Restrição Externa}

O estudo empírico, reportado e comentado no que segue, pretendeu investigar em que medida o crescimento econômico brasileiro esteve relacionado à melhora nas condições de restrição externa, no sentido apresentado por McCombie e Thirwall (1994) e que, por sua vez, está correlacionado com a análise cepalina que relaciona um bom posicionamento no mercado externo com o desempenho econômico. Dessa forma, nesta seção será apresentado o modelo de restrição externa, base do teste empírico subsequente.

As análises mais convencionais, tipicamente neoclássicas, do processo de crescimento econômico focalizam exclusivamente os determinantes da expansão do produto no lado da capacidade de ofertar bens e serviços, ou seja, a acumulação de estoques de capital físico e humano, tecnologia etc. Por sua vez, Thirlwall, assim como outros autores inspirados em Keynes, propõe considerar que, em geral, antes de exaurir-se tal potencial de geração do produto de um país, restrições na demanda agregada por bens e serviços apresentam-se como fator de limitação mais significativo. Além disso, no contexto de economias abertas, Thirlwall assinala que as restrições quanto à disponibilidade de divisas tendem a apresentar-se como o principal obstáculo a níveis mais elevados de demanda agregada.

De acordo com Lei de Thirlwall, ${ }^{4}$ derivada formalmente a seguir, a taxa de crescimento do país não poderá se distanciar muito da seguinte conta: a taxa de crescimento do produto mundial, multiplicada pela elasticidade-renda das exportações e dividida pela elasticidade-renda das importações. Dado certo ritmo de crescimento no produto mundial, as vendas externas do país aumentarão conforme a elasticidade-renda das exportações. Por outro lado, essa expansão nas receitas elevará a margem de manobra para o crescimento doméstico apenas na extensão em que for mais ou menos absorvida por elevação das importações, conforme sua elasticidade-renda. $\mathrm{O}$ ingresso líquido de capitais externos provê a possibilidade de desvios em relação a essa conta, porém dentro de certos limites. Por exemplo, quando é alta a rentabilidade do capital externo ingressado e esse aporte de capital não se traduz em mudanças na configuração de elasticidades-renda de exportações ou importações, seu serviço posterior tende a aumentar a carga da restrição de divisas ao crescimento.

4 Muito embora o próprio Thirlwall (MCCOMBIE; THIRWALL, 1994) tenha mencionado posteriormente que "fato estilizado" ou "generalização empírica" talvez seja uma melhor descrição que "Lei" para o que veio a ser conhecido como a Lei de Thirlwall. 
Desde logo, é fundamental esclarecer que a abordagem do crescimento sob restrição externa à Thirlwall, não obstante esteja assentada no pressuposto de que restrições na demanda agregada apresentam-se como fator de limitação mais significativo ao crescimento econômico no longo prazo, não ignora a relevância de fatores associados à oferta agregada. Afinal, as elasticidades-renda são o reflexo de uma variedade de fatores em nível de oferta que condicionam a competitividade estrutural da economia. ${ }^{5}$

Evidentemente, a restrição comercial determinada por elasticidades-renda pode vir a ser alterada por mudanças nos patamares da taxa real de câmbio. Entretanto, depreende-se da Lei de Thirlwall que para um desvio definitivo em relação às elasticidades-renda, a economia teria de apresentar processos de desvalorização ou valorização cambial real permanente. Logo, a competitividade estrutural do país, conforme refletida nas elasticidades-renda de exportações e importações, acaba, através destas últimas, determinando seu potencial de crescimento. Daí depreende-se, por conseguinte, a necessidade de melhora na competitividade estrutural brasileira como requisito para maior crescimento.

Em sua formulação inicial, Thirlwall (1979) assim especifica a condição de equilíbrio externo:

$$
P_{d} X=P_{f} M E
$$

onde $X$ é a quantidade de exportações de bens e serviços não fatores, $P_{d}$ é o preço das exportações em moeda nacional, $M$ é a quantidade de importações de bens e serviços não fatores de produção, $P_{f}$ é o preço das importações em moeda estrangeira e $E$ é a taxa de câmbio nominal. Nessa formulação inicial, portanto, o equilíbrio externo envolve somente a balança comercial. Expressando as variáveis da equação (1) em termos de taxa de crescimento, obtemos:

$$
p_{d}+x=p_{f}+m+e
$$

onde as letras em minúsculo indicam as respectivas taxas de crescimento. Assumindo formas multiplicativas tradicionais, com elasticidades constantes, para as importações e as exportações, em termos das taxas de crescimento, obtemos:

$5 \quad$ Como bem assinalado, por exemplo, em McCombie e Thirlwall (1994, p. 391): "Income elasticities determine the balance-of-payments constrained growth rate, but the supply characteristics of goods (such as their technical sophistication, quality etc.) determine relative income elasticities. In this important respect, there can be a marrying of the demand and supply side explanations of the comparative growth performance of nations". 


$$
\begin{gathered}
m=\psi\left(p_{f}+e-p_{d}\right)+\pi y \\
x=\eta\left(p_{d}-e-p_{f}\right)+\varepsilon z
\end{gathered}
$$

Por meio da substituição das equações (3) e (4) na equação (2), obtemos então a taxa de crescimento restringida pelo equilíbrio externo:

$$
y_{b p}=\frac{(1+\eta+\psi)\left(p_{d}-e-p_{f}\right)+\varepsilon z}{\pi}
$$

Nessa formulação inicial, assim como nas seguintes, Thirlwall (1979) assume que, no longo prazo, a variação nos termos de troca, se alguma, é negligenciável. Logo, a equação (5) se reduz a:

$$
y_{b p}=\frac{x}{\pi}
$$

posto que $x=\varepsilon z$ é a taxa de crescimento das exportações. Assim sendo, $y_{b p}$ representa a taxa de crescimento do produto consistente com a satisfação da restrição relativa ao estabelecimento do equilíbrio externo.

\section{Metodologia do Teste Empírico}

Com o objetivo de identificar as possíveis quebras nas variáveis centrais - elasticidades-renda das exportações e importações - estimou-se, através da técnica de Mínimos Quadrados Ordinários (MQO), as funções demanda de importações (equação 3) e demanda de exportações (equação 4) em primeiras diferenças.

Diversos estudos empíricos estimam as funções de importação e exportação em nível, utilizando-se a técnica de cointegração, já que as variáveis envolvidas são potencialmente geradas por processos estocásticos de ordem 1. A literatura econométrica de séries de tempo, desenvolvida a partir dos trabalhos de Engle e Granger (1987) e de Johansen (1995), levanta os problemas relacionados à estimação por mínimos quadrados a partir de séries não estacionárias. Assim, o uso de primeiras diferenças, embora resolva o problema da regressão espúria, incorreria no problema de perder a informação de longo prazo da série.

No entanto, segundo McCombie (1997), é difícil perceber o porquê da perda de informação de longo prazo ao utilizar esse modelo em 
primeira diferença, ao invés do nível, dado que o modelo em si é uma explicação das diferentes taxas de crescimento e não do nível. O fato de o modelo aplicar-se no longo prazo está sendo considerado quando nas estimações utilizam-se diversos anos. Diversos estudos empíricos têm demonstrado que a estimação em primeiras diferenças tem se mostrado adequada e pouco difere das estimações em nível, usando cointegração.

Com o suporte dessa análise, o estudo empírico utilizará a técnica de Mínimos Quadrados Ordinários. Além da positiva simplicidade da técnica econométrica, este método permite introduzir mais claramente a quebra estrutural nas elasticidades-renda através de dummies de declividade. $^{6}$

Assim, foram estimadas as funções de importação e exportação por MQO em primeiras diferenças, e incluídas em cada função duas variáveis dummies para o período em questão: uma variável dummy de intercepto e uma dummy de declividade, interagindo com o coeficiente de renda interna (importações) e externa (exportações), respectivamente.

Em primeiro lugar, o modelo é estimado com a inclusão de ambas as dummies, a de declividade e a de intercepto (Modelo I). No contexto do modelo macroeconômico utilizado, a significância da dummy de declividade implica uma mudança nos parâmetros estruturais do modelo e, portanto, provoca uma mudança na resposta das importações à renda interna (ou das exportações à renda externa), possibilitando o aumento ou redução da taxa de crescimento do produto. Já a significância da dummy de intercepto implica um salto do nível, mas não a mudança na dinâmica de manifestação da restrição externa.

No entanto, ainda em um modelo com dummies de intercepto e declividade, a não significância de ambas as variáveis não necessariamente implica a ausência de quebras, pois, devido ao problema de multicolineriedade, os efeitos do intercepto e da declividade podem estar se confundindo. Nesse caso, parte-se para outro modelo, que testa separadamente a dummy de declividade e, posteriormente, a de intercepto (Modelo II). Caso verifique-se a relevância apenas da dummy de declividade, conclui-se por uma quebra estrutural. Já se verificada a relevância apenas da dummy de intercepto, conclui-se por uma quebra

6 Embora existam métodos de se introduzir uma quebra estrutural no vetor de cointegração através, por exemplo, de tendências associadas com dummies, ou divisão das séries, esses métodos, ou não captam exatamente alterações nas elasticidades-renda, ou não são possíveis para quebras estruturais no final da série. Por outro lado, a introdução de dummies de declividade diretamente no vetor de cointegração não é um procedimento correto, pois altera a função de distribuição, como coloca Seo (1995). 
de nível. Se mesmo nos modelos que testam as duas dummies separadamente, ambas apresentarem-se não significativas, conclui-se pela não existência de quebra.

Porém, ainda resta outro caso, no qual o modelo com dummies de intercepto e declividade (Modelo I) verifica-se a não significância de ambas e no qual o modelo que testa cada uma separadamente as duas variáveis apresentam-se significantes. Nesse caso, conclui-se pela existência da quebra, mas essa é indefinida, ou seja, não está claro se a quebra ocorreu no nível ou na resposta à variável. Nesse caso, o resultado será classificado como quebra indefinida.

Ressalta-se que, no âmbito do modelo apresentado na seção anterior, apenas a alteração da declividade representa uma mudança estrutural na manifestação da restrição externa que leva a diferentes taxas de crescimento do produto.

A Tabela 1 associa o modelo de teste, o resultado econométrico, e a referente conclusão no âmbito do modelo desenvolvido neste texto.

Tabela 1 - Metodologia do Estudo das Quebras Estruturais

\begin{tabular}{|c|c|c|c|}
\hline \multicolumn{4}{|c|}{ ESTUDO DE QUEBRAS ESTRUTURAIS } \\
\hline \multicolumn{4}{|c|}{$\begin{array}{l}\text { Elasticidade-Renda (declividade): quebra afeta a taxa de crescimento } \\
\text { do produto de longo prazo }\end{array}$} \\
\hline \multicolumn{4}{|c|}{ Elasticidade-Renda (intercepto): quebra afeta nível once-for-all } \\
\hline Modelo Teste & $\begin{array}{c}\text { Resultado } \\
\text { Declividade }\end{array}$ & $\begin{array}{l}\text { Resultado } \\
\text { Intercepto }\end{array}$ & Conclusão \\
\hline \multirow{4}{*}{$\begin{array}{c}\text { Modelo I } \\
\text { Intecepto e } \\
\text { Declividade } \\
\text { Conjuntamente }\end{array}$} & declividade significante & $\begin{array}{l}\text { intercepto não } \\
\text { significante }\end{array}$ & quebra estrutural \\
\hline & declividade significante & intercepto significante & $\begin{array}{l}\text { quebra estrutural + } \\
\text { nível }\end{array}$ \\
\hline & $\begin{array}{l}\text { declividade não } \\
\text { significante }\end{array}$ & intercepto significante & quebra de nível \\
\hline & $\begin{array}{l}\text { declividade não } \\
\text { significante }\end{array}$ & $\begin{array}{l}\text { intercepto não } \\
\text { significante }\end{array}$ & $\begin{array}{l}\text { testa-se modelo ii } \\
\text { (multicolinearidade) }\end{array}$ \\
\hline \multirow{4}{*}{$\begin{array}{l}\text { Modelo II } \\
\text { Intecepto e Decli- } \\
\text { vidade }\end{array}$} & declividade significante & $\begin{array}{c}\text { intercepto não } \\
\text { significante }\end{array}$ & quebra estrutural \\
\hline & $\begin{array}{l}\text { declividade não } \\
\text { significante }\end{array}$ & intercepto significante & quebra de nível \\
\hline & $\begin{array}{l}\text { declividade não } \\
\text { significante }\end{array}$ & $\begin{array}{l}\text { intercepto não } \\
\text { significante }\end{array}$ & não quebra \\
\hline & declividade significante & intercepto significante & quebra indefinida \\
\hline
\end{tabular}

Fonte: Elaborada pelas autoras.

$\mathrm{Na}$ estimação dos modelos e nos testes posteriores utilizaram-se dados anuais da economia brasileira entre 1931 e 2007 e um índice de 
crescimento da economia mundial no mesmo período. ${ }^{7}$ Os dados foram obtidos no Ipeadata. ${ }^{8}$ Quanto à construção da série de câmbio real $\left(\mathrm{P}_{\mathrm{f}} \mathrm{E} /\right.$ $\mathrm{P}_{\mathrm{d}}$ ), utilizou-se como medida para $\mathrm{P}_{\mathrm{f}}$ os tradables americanos (IPA-EUA) e para $\mathrm{P}_{\mathrm{d}}$ os non-tradables locais (IPC-FIPE), ou seja, a medida mais tradicional de câmbio real.

\section{Resultados Empíricos}

As funções de demanda por importação (equação 3) e exportação (equação 4) foram estimadas para todo o período da amostra 1931 a 2007, de acordo com a metodologia descrita anteriormente. Em cada estimação foram incluídas as dummies de declividade e intercepto correspondentes a cada um dos nove subperíodos descritos na seção 2. Deste modo, foram realizadas nove estimações de cada função de demanda. As Tabelas 2 e 3 apresentam os resultados para as funções de importação e exportação, respectivamente.

Tabela 2 - Resultados Elasticidade Renda das Importações

\begin{tabular}{|c|c|c|c|c|c|c|c|c|c|c|}
\hline & \multicolumn{9}{|c|}{ ELASTICIDADE RENDA DAS IMPORTAÇÕES } & \multirow{3}{*}{$\begin{array}{c}\begin{array}{c}\text { Conclu- } \\
\text { sões }\end{array} \\
(10 \% \\
\text { signif. })\end{array}$} \\
\hline & \multirow[b]{2}{*}{ Períodos } & \multirow[b]{2}{*}{$\begin{array}{l}\text { Dummy } \\
\text { Período }\end{array}$} & \multicolumn{3}{|c|}{$\begin{array}{l}\text { Modelo Declividade + } \\
\text { Intercepto }\end{array}$} & \multicolumn{2}{|c|}{$\begin{array}{c}\text { Modelo } \\
\text { Declividade }\end{array}$} & \multicolumn{2}{|c|}{$\begin{array}{c}\text { Modelo } \\
\text { Intercepto }\end{array}$} & \\
\hline & & & $\begin{array}{l}\text { Coefi- } \\
\text { ciente } \\
\text { Renda }\end{array}$ & $\begin{array}{c}\text { Dummy } \\
\text { Declivi- } \\
\text { dade }\end{array}$ & $\begin{array}{l}\text { Dummy } \\
\text { Inter- } \\
\text { cepto } \\
\end{array}$ & $\begin{array}{l}\text { Coefi- } \\
\text { ciente } \\
\text { Renda }\end{array}$ & $\begin{array}{l}\text { Dummy } \\
\text { Declivi- } \\
\text { dade }\end{array}$ & $\begin{array}{l}\text { Coefi- } \\
\text { ciente } \\
\text { Renda }\end{array}$ & $\begin{array}{c}\text { Dummy } \\
\text { Inter- } \\
\text { cepto } \\
\end{array}$ & \\
\hline & $\begin{array}{c}\text { Todo } \\
\text { Período }\end{array}$ & $1932-07$ & 1.88 & & & & & & & \\
\hline & & & 0.00 & & & & & & & \\
\hline $\mathbf{I}$ & $\begin{array}{c}\text { Estado } \\
\text { Novo } \\
\text { (Probabi- } \\
\text { lidade-\%) }\end{array}$ & $1937-44$ & $\begin{array}{l}1.78 \\
0.00\end{array}$ & $\begin{array}{l}3.43 \\
5.57\end{array}$ & $\begin{array}{l}-0.14 \\
9.87\end{array}$ & - & - & - & - & $\begin{array}{l}\text { Quebra } \\
\text { Dupla } \\
\text { (oposta) }\end{array}$ \\
\hline 2 & $\begin{array}{c}\text { Era } \\
\text { Dutra- } \\
\text { Vargas }\end{array}$ & $\begin{array}{c}1945- \\
55\end{array}$ & 1.94 & -2.69 & 0.17 & 1.94 & -0.36 & 1.86 & 0.00 & Não \\
\hline
\end{tabular}

(continua)

7 Devido a discrepância dos dados para o ano de 1930, optou por iniciar a amostra com os dados de 1931.

8 Para dados de Balanço de Pagamentos entre 1947-2007, a fonte original é BCB, enquanto entre 1930-1946, o IPEA compilou dados de diversos autores. Todas as séries de Balanço de Pagamentos em dólares foram deflacionadas pelo IPC americano. A série de câmbio nominal tem como fonte original BCB entre 1942-2007, enquanto entre 1930-1942, o IPEA compilou dados de diversos autores. As séries de PIB a preços constantes têm como fonte original o BNDES entre 1947-2007, e entre 1930-1947 o IPEA construiu a série. A taxa de crescimento mundial tem como fonte original o World Bank. 


\begin{tabular}{|c|c|c|c|c|c|c|c|c|c|c|}
\hline \multirow{3}{*}{3} & $\begin{array}{l}\text { (Probabi- } \\
\text { lidade-\%) }\end{array}$ & & 0.00 & 21.64 & 24.59 & 0.00 & 66.55 & 0.00 & 95.78 & Quebra \\
\hline & $\begin{array}{c}\text { Plano de } \\
\text { Metas }\end{array}$ & $\begin{array}{c}1956- \\
61\end{array}$ & 2.12 & 0.28 & -0.18 & 2.12 & -1.79 & 2.12 & -0.16 & Quebra \\
\hline & $\begin{array}{l}\text { (Probabi- } \\
\text { lidade-\%) }\end{array}$ & & 0.00 & 92.77 & 47.83 & 0.00 & 5.69 & 0.00 & 4.22 & $\begin{array}{c}\text { Indefi- } \\
\text { nida } \\
\text { (dimi- } \\
\text { nuição) }\end{array}$ \\
\hline \multirow[t]{2}{*}{4} & PAEG & $\begin{array}{c}1962- \\
67\end{array}$ & 1.92 & 2.06 & -0.16 & 1.92 & -1.15 & 1.94 & -0.08 & \\
\hline & $\begin{array}{l}\text { (Probabi- } \\
\text { lidade-\%) }\end{array}$ & & 0.00 & 55.15 & 28.93 & 0.00 & 49.22 & 0.00 & 26.33 & Quebra \\
\hline \multirow[t]{2}{*}{5} & $\begin{array}{l}\text { Milagre } \\
\text { Econ. }\end{array}$ & $\begin{array}{c}1967- \\
74\end{array}$ & 1.92 & 2.06 & -0.16 & 1.54 & 1.29 & 1.54 & 0.13 & Quebra \\
\hline & $\begin{array}{l}\text { (Probabi- } \\
\text { lidade-\%) }\end{array}$ & & 0.00 & 55.15 & 28.93 & 0.00 & 8.02 & 0.00 & 6.65 & $\begin{array}{c}\text { Indefi- } \\
\text { nida } \\
\text { (au- } \\
\text { mento) }\end{array}$ \\
\hline \multirow[t]{2}{*}{6} & II PND & $\begin{array}{c}1974- \\
82\end{array}$ & 1.74 & 1.00 & 0.00 & 1.74 & 1.03 & 1.80 & 0.05 & Não \\
\hline & $\begin{array}{l}\text { (Probabi- } \\
\text { lidade-\%) }\end{array}$ & & 0.00 & 49.88 & 98.07 & 0.00 & 29.70 & 0.00 & 42.95 & Quebra \\
\hline \multirow[t]{2}{*}{7} & Crise 80 & $\begin{array}{c}1982- \\
92\end{array}$ & & & & & 0.48 & 1.88 & & Não \\
\hline & $\begin{array}{l}\text { (Probabi- } \\
\text { lidade-\%) }\end{array}$ & & 0.00 & 40.34 & 76.25 & 0.00 & 3.07 & 0.00 & 78.01 & Quebra \\
\hline \multirow[t]{2}{*}{8} & $\begin{array}{c}\text { Abertura } \\
90\end{array}$ & $\begin{array}{c}1992- \\
02\end{array}$ & 1.73 & 3.58 & 0.00 & 1.73 & 3.61 & 1.78 & 0.09 & Quebra \\
\hline & $\begin{array}{l}\text { (Probabi- } \\
\text { lidade-\%) }\end{array}$ & & 0.00 & 20.88 & 99.03 & 0.00 & 3.93 & 0.00 & 10.40 & $\begin{array}{c}\text { Estru- } \\
\text { tural } \\
\text { (au- } \\
\text { mento) }\end{array}$ \\
\hline \multirow[t]{2}{*}{9} & $\begin{array}{c}\text { Governo } \\
\text { Lula }\end{array}$ & $\begin{array}{c}2003- \\
07\end{array}$ & 1.84 & 2.92 & 0.00 & 1.84 & 2.99 & 1.85 & 0.08 & Não \\
\hline & $\begin{array}{l}\text { (Probab1- } \\
\text { lidade-\%) }\end{array}$ & & 0.00 & 61.67 & 98.98 & 0.00 & 31.72 & 0.00 & 38.76 & Quebra \\
\hline
\end{tabular}

Fonte: Elaborada pelas autoras.

Observa-se que houve quebra na elasticidade-renda da importação em quatro subperíodos: Estado Novo, Plano de Metas, Milagre Econômico e no período da Abertura na década de 1990. No Estado Novo, verificou-se quebra dupla e oposta: observou-se um aumento na elasticidade-renda da importação, o que também aumenta a restrição externa ao crescimento, e uma queda no intercepto da função, o que representa uma queda no nível de importações. Tanto no Plano de 
Metas quanto no período do Milagre Econômico, constatou-se quebra indefinida, mas em sentidos opostos: no Plano de Metas, houve queda na elasticidade-renda da importação, o que reduz a restrição externa ao crescimento, enquanto que no Milagre Econômico houve aumento dessa elasticidade, o que eleva a restrição. Em relação ao intercepto, o sentido manteve-se: no Plano de Metas observou-se queda no nível de importações, enquanto que no Milagre Econômico houve aumento deste nível. No período da Abertura, a quebra observada foi uma quebra estrutural, com aumento da elasticidade-renda da importação.

Tabela 3 - Resultados Elasticidade Renda das Exportações

\begin{tabular}{|c|c|c|c|c|c|c|c|c|c|c|}
\hline & \multicolumn{9}{|c|}{ ELASTICIDADE RENDA DAS EXPORTAÇÕES } & \multirow{3}{*}{$\begin{array}{c}\text { Conclu- } \\
\text { sões } \\
(10 \% \\
\text { signif.) }\end{array}$} \\
\hline & \multirow[b]{2}{*}{ Períodos } & & \multicolumn{3}{|c|}{$\begin{array}{c}\text { Modelo Declividade + } \\
\text { Intercepto }\end{array}$} & \multicolumn{2}{|c|}{$\begin{array}{c}\text { Modelo } \\
\text { Declividade }\end{array}$} & \multicolumn{2}{|c|}{$\begin{array}{c}\text { Modelo } \\
\text { Intercepto }\end{array}$} & \\
\hline & & & $\begin{array}{l}\text { Coefi- } \\
\text { ciente } \\
\text { Renda }\end{array}$ & $\begin{array}{c}\text { Dummy } \\
\text { Declivi- } \\
\text { dade }\end{array}$ & $\begin{array}{l}\text { Dummy } \\
\text { Inter- } \\
\text { cepto }\end{array}$ & $\begin{array}{l}\begin{array}{l}\text { Coefi- } \\
\text { ciente } \\
\text { Renda }\end{array} \\
\end{array}$ & $\begin{array}{l}\text { Dummy } \\
\text { Declivi- } \\
\text { dade }\end{array}$ & $\begin{array}{l}\text { Coefi- } \\
\text { ciente } \\
\text { Renda }\end{array}$ & $\begin{array}{c}\text { Dummy } \\
\text { Inter- } \\
\text { cepto }\end{array}$ & \\
\hline & $\begin{array}{l}\text { Todo } \\
\text { Período }\end{array}$ & $\begin{array}{c}1932- \\
06\end{array}$ & $\begin{array}{l}1.30 \\
0.10\end{array}$ & & & & & & & \\
\hline $\mathbf{1}$ & \begin{tabular}{|c|} 
Estado \\
Novo \\
(Proba- \\
bili- \\
dade-\%)
\end{tabular} & $\begin{array}{c}1937- \\
44\end{array}$ & $\begin{array}{l}1.30 \\
0.00\end{array}$ & $\begin{array}{l}-1.10 \\
42.90\end{array}$ & $\begin{array}{r}0.10 \\
45.20\end{array}$ & $\begin{array}{l}1.30 \\
0.00\end{array}$ & $\begin{array}{l}-0.30 \\
75.40\end{array}$ & $\begin{array}{l}1.30 \\
0.00\end{array}$ & $\begin{array}{l}0.00 \\
84.40\end{array}$ & $\begin{array}{c}\text { Não } \\
\text { Quebra }\end{array}$ \\
\hline 2 & \begin{tabular}{|c|} 
Era \\
Dutra- \\
Vargas \\
(Proba- \\
bili- \\
dade-\%)
\end{tabular} & $\begin{array}{c}1945- \\
55\end{array}$ & $\begin{array}{l}1.61 \\
0.00\end{array}$ & $\begin{array}{l}-2.57 \\
\mathbf{0 . 1 3}\end{array}$ & $\begin{array}{l}0.10 \\
1.52\end{array}$ & & & & & $\begin{array}{c}\text { Quebra } \\
\text { Dupla } \\
\text { (oposta) }\end{array}$ \\
\hline 3 & \begin{tabular}{|c} 
Plano de \\
Metas \\
(Proba- \\
bili- \\
dade-\%)
\end{tabular} & $\begin{array}{c}1956- \\
61\end{array}$ & $\begin{array}{l}1.32 \\
0.00\end{array}$ & $\begin{array}{r}0.68 \\
78.92\end{array}$ & $\begin{array}{l}-0.06 \\
51.35\end{array}$ & $\begin{array}{l}1.32 \\
0.00\end{array}$ & $\begin{array}{l}-0.56 \\
74.49\end{array}$ & $\begin{array}{l}1.32 \\
0.00\end{array}$ & $\begin{array}{l}-0.04 \\
49.46\end{array}$ & $\begin{array}{c}\text { Não } \\
\text { Quebra }\end{array}$ \\
\hline 4 & $\begin{array}{c}\text { PAEG } \\
\text { (Proba- } \\
\text { bili- } \\
\text { dade-\%) }\end{array}$ & $\begin{array}{c}1962- \\
67\end{array}$ & $\begin{array}{l}1.34 \\
0.00\end{array}$ & $\begin{array}{r}6.19 \\
52.49\end{array}$ & $\begin{array}{l}-0.35 \\
47.14\end{array}$ & $\begin{array}{l}1.35 \\
0.00\end{array}$ & $\begin{array}{l}-0.77 \\
51.26\end{array}$ & $\begin{array}{l}1.35 \\
0.00\end{array}$ & $\begin{array}{l}-0.04 \\
45.05\end{array}$ & $\begin{array}{c}\text { Não } \\
\text { Quebra }\end{array}$ \\
\hline 5 & $\begin{array}{l}\text { Milagre } \\
\text { Econ. }\end{array}$ & $\begin{array}{c}1967- \\
74\end{array}$ & 1.10 & 3.87 & -0.03 & 1.10 & 3.22 & 1.12 & 0.13 & Quebra \\
\hline
\end{tabular}




\begin{tabular}{|c|c|c|c|c|c|c|c|c|c|c|}
\hline & $\begin{array}{c}\text { (Proba- } \\
\text { bili- } \\
\text { dade-\%) }\end{array}$ & & 0.02 & 35.72 & 87.24 & 0.02 & 0.43 & 0.01 & 0.01 & $\begin{array}{l}\text { Indefinida } \\
\text { (aumento) }\end{array}$ \\
\hline 6 & $\begin{array}{l}\text { II PND } \\
\text { (Proba- } \\
\text { bili- } \\
\text { dade-\%) }\end{array}$ & $\begin{array}{c}1974- \\
82\end{array}$ & $\begin{array}{l}1.18 \\
0.01\end{array}$ & $\begin{array}{r}1.95 \\
51.84\end{array}$ & $\begin{array}{l}0.04 \\
67.43\end{array}$ & $\begin{array}{l}1.18 \\
0.01\end{array}$ & $\begin{array}{l}3.07 \\
\mathbf{3 . 1 1}\end{array}$ & $\begin{array}{l}1.19 \\
0.01\end{array}$ & $\begin{array}{l}0.10 \\
3.59\end{array}$ & $\begin{array}{l}\text { Quebra } \\
\text { Indefinida } \\
\text { (aumento) }\end{array}$ \\
\hline 7 & $\begin{array}{c}\text { Crise } 80 \\
\text { (Proba- } \\
\text { bili- } \\
\text { dade-\%) }\end{array}$ & $\begin{array}{c}1982- \\
92\end{array}$ & $\begin{array}{l}1.28 \\
0.00\end{array}$ & $\begin{array}{l}3.43 \\
33.86\end{array}$ & $\begin{array}{l}-0.10 \\
37.07\end{array}$ & $\begin{array}{l}1.28 \\
0.00\end{array}$ & $\begin{array}{r}0.47 \\
73.25\end{array}$ & $\begin{array}{l}1.30 \\
0.00\end{array}$ & $\begin{array}{r}0.00 \\
97.61\end{array}$ & $\begin{array}{c}\text { Não } \\
\text { Quebra }\end{array}$ \\
\hline 8 & $\begin{array}{c}\text { Aber- } \\
\text { tura } 90 \\
\text { (Proba- } \\
\text { bili- } \\
\text { dade-\%) }\end{array}$ & $\begin{array}{c}1992- \\
02\end{array}$ & $\begin{array}{l}1.26 \\
0.01\end{array}$ & $\begin{array}{c}0.75 \\
89.96\end{array}$ & $\begin{array}{c}0.00 \\
98.83\end{array}$ & $\begin{array}{l}1.26 \\
0.00\end{array}$ & $\begin{array}{c}0.83 \\
54.28\end{array}$ & $\begin{array}{l}1.26 \\
0.00\end{array}$ & $\begin{array}{r}0.03 \\
55.16\end{array}$ & $\begin{array}{c}\text { Não } \\
\text { Quebra }\end{array}$ \\
\hline 9 & $\begin{array}{c}\text { Governo } \\
\text { Lula } \\
\text { (Proba- } \\
\text { bili- } \\
\text { dade-\%) }\end{array}$ & \begin{tabular}{|c|}
$2003-$ \\
07
\end{tabular} & $\begin{array}{l}1.20 \\
0.00\end{array}$ & $\begin{array}{r}7.85 \\
61.47\end{array}$ & $\begin{array}{l}-0.18 \\
\mathbf{7 8 . 3 9}\end{array}$ & $\begin{array}{l}1.20 \\
0.00\end{array}$ & 3.60 & $\begin{array}{l}1.20 \\
0.00\end{array}$ & $\begin{array}{l}0.15 \\
\mathbf{2 . 8 7}\end{array}$ & $\begin{array}{c}\text { Quebra } \\
\text { Indefinida }\end{array}$ \\
\hline
\end{tabular}

Fonte: Elaborada pelas autoras.

Em relação à função de demanda por exportação, observa-se quebra na elasticidade-renda em quatro subperíodos: Era Dutra-Vargas, Milagre Econômico, II PND e no Governo Lula. Na Era Dutra-Vargas, a queda observada é dupla, tanto na elasticidade-renda da exportação quanto no intercepto do modelo, mas em sentidos opostos. A elasticidade-renda da exportação apresenta queda, o que aumenta a restrição externa, e para o intercepto verifica-se aumento no nível. Tanto no período do Milagre Econômico quanto no II PND, observou-se quebra indefinida e no mesmo sentido: houve aumento na elasticidade-renda das exportações, o que leva à redução da restrição externa, e ao aumento no nível das exportações, dado o aumento no intercepto. No Governo Lula, o resultado anterior se repete: verificou-se quebra indefinida.

É interessante notar que as quebras apontadas para a função de demanda por importação são semelhantes às constatadas por Giuberti (s/d), a partir de outra metodologia de estimação. Neste artigo, a autora utiliza o método de mínimos quadrados recursivos para estudar a instabilidade dos parâmetros da função de demanda por importação. Essa metodologia permite testar se houve quebra(s) estrutural (estruturais) no modelo sem a necessidade de se definir a priori o(s) períodos(s) em que essa(s) quebra(s) ocorreu(ram). É a partir da análise dos resíduos 
recursivos que a presença ou não de quebra(s) é(são) então constatada(s). De acordo com os testes de previsão, um passo à frente e n-passos à frente, ${ }^{9}$ apresentados no Gráfico 1 , a função de demanda por importação apresenta quebra estrutural na primeira metade da década de 1970 e no início dos anos 1990, consoante às quebras reportadas acima no período do Milagre Econômico e na Abertura dos anos 1990.

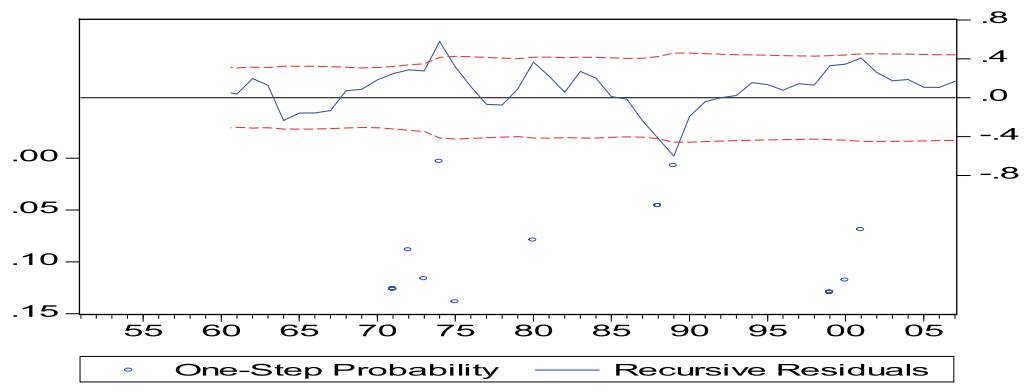

Gráfico 1 - Resultado do Teste de Instabilidade dos Parâmetros Fonte: Giuberti (s/d).

Além disso, a variação encontrada pela autora para a elasticidaderenda da importação apresenta o mesmo sentido da constatada na Tabela 2. Para ambos os períodos, observa-se um aumento na elasticidade-renda da importação (Gráfico 2), o que representa um aumento da restrição externa ao crescimento da economia.

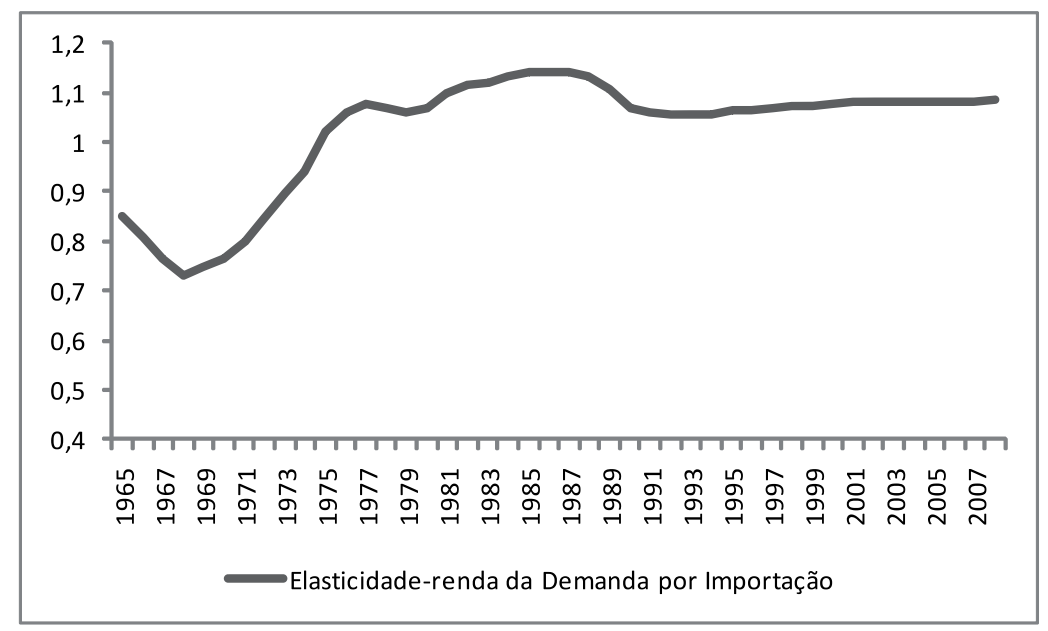

Gráfico 2 - Elasticidade-Renda da Demanda por Importação

Fonte: Giuberti (s/d)

9 O método de mínimos quadrados recursivos e a metodologia dos teste de previsão um passo a frente e n-passos a frente encontram-se descritos em Giuberti (s/d). 


\section{Interpretação dos Resultados}

\subsection{Período 1937-1944}

No início do Estado Novo, entre 1937-1939, observou-se uma retração das receitas de exportação. O café, principal produto da pauta, não estava ligado a esse resultado. Pelo contrário, a elasticidade-preço do café mostrou-se alta no curto prazo com um aumento na quantidade exportada de $40 \%$, frente a uma queda de $25 \%$ nos preços. Foi a retração de outras receitas de exportação que gerou o resultado citado (ABREU, $1990 b$, p. 91). Só após a entrada dos EUA na II Guerra Mundial e dos acordos de suprimento de materias, bem como o aumento da demanda por produtos brasileiros em mercados antes supridos pelos EUA e Reino Unido que se observou uma expansão das exportações. Ainda assim, não se verificou nenhuma quebra na elasticidade-renda das exportações.

Já no caso das importações, a forte desvalorização e as restrições às importações face à guerra foram eficazes na contenção do nível de importações, refletido na quebra (diminuição) do intercepto. A necessidade por importações para dar andamento ao PSI (como os materiais para Companhia Siderurgica Nacional) e a retenção da demanda de importações, por sua vez, afetaram a elasticidade-renda das importações, que registrou um aumento no período. Essas variáveis levaram a um crescimento mais baixo nos anos 1937-1945, como pode ser visto no Gráfico 3.

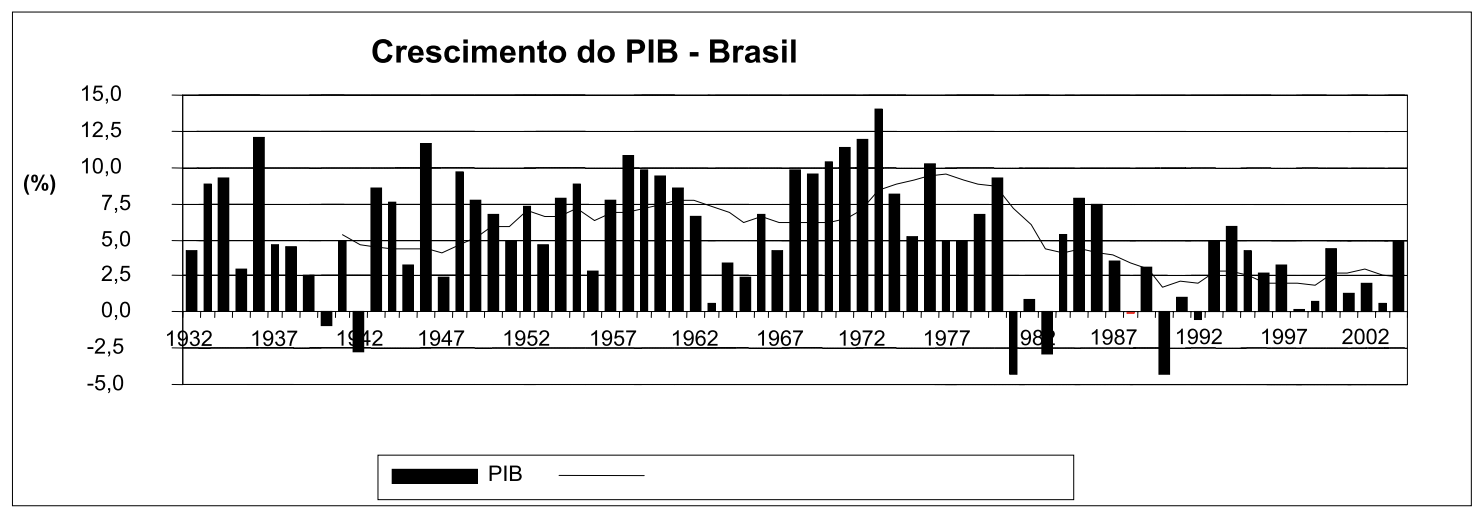

Gráfico 3 - Crescimento Brasileiro 1932- 2006

Fonte: Elaborado pelas autoras com base no Ipeadata. 


\subsection{Período 1945-1954}

Na Era Dutra-Vargas, como mencionado anteriormente, ocorre o aprofundamento do PSI brasileiro, com aumento da intervenção estatal na economia, vista, em particular, nos controles cambiais implementados com a escassez de divisas, como as licenças de importação e as taxas de câmbio múltiplo a partir de 1952. As licenças possibilitaram direcionar as importações para o investimento e restringir as importações que concorriam com a produção nacional, particularmente de bens de consumo. Com o sistema de taxas de câmbio múltiplo, o escopo da política foi ampliado. Entretanto, de acordo com o modelo, esses controles não afetaram os parâmetros da função de importação, dado que não se observou quebra estrutural.

Por outro lado, ocorreu uma diminuição considerável das receitas de exportação não tradicionais, devido à redução da demanda por produtos brasileiros por parte da Europa, que estava em reconstrução, redução esta contrabalançada pelo contínuo aumento das receitas de café. O resultado agregado foi exportações maiores (efeito captado pelo aumento no intercepto da função de exportação) e mais inelásticas (redução na elasticidade-renda da exportação). A queda verificada na elasticidade-renda do período está ligada ao aumento da participação do café na pauta exportadora e à própria demanda por café, cuja característica principal é ter baixa elasticidade-renda.

Embora o processo de substituição de importação do período não tenha tido impacto nos parâmetros de importação, a taxa de crescimento do produto mais elevada no período (Gráfico 3) esteve ligada ao aprofundamento desse processo que, por meio de Licenças de Importação ou Taxas de Câmbio Multiplas, penalizava os produtos concorrentes e promovia os produtos necessários à produção nacional. Do mesmo modo, esse crescimento teve como apoio o aumento do nível de exportações, apesar da redução da sua elasticidade-renda.

\subsection{Período 1955-1961}

Como resultado das políticas implementadas no Plano de Metas, o modelo identificou uma quebra na função de importação, porém não definida: houve uma queda significativa da elasticidade-renda das importações e uma diminuição no nível, quando as dummies foram estimadas separadamente. Essa redução da restrição externa foi uma das variáveis que possibilitou que o país crescesse cerca de 50\% neste período de 5 anos, como pode ser visualizado no Gráfico 3.

Vale ressaltar que as políticas adotadas visavam à substituição de importação, e não à promoção de exportações. Todas as quebras nas 
elasticidades-rendas das exportações até aqui ocorreram devido a fenômenos externos: guerra, fim da guerra, Grande Depressão. Por essa razão, mesmo em um período de profundas transformações econômicas como o Governo Kubitschek, nenhuma quebra foi verificada na elasticidade-renda das exportações.

\subsection{Período 1962-1967}

Neste período, não se verificou quebra nos parâmetros das funções de importação e de exportação, nem no intercepto nem na declividade. Este resultado era esperado, pois as políticas do período foram marcadas mais pelo objetivo de estabilização da economia do que pela intenção de promover diretamente uma mudança na estrutura produtiva. Como descrito na seção 2, o PAEG foi concebido como um plano de curto prazo para enfrentar a crise marcada pela queda no crescimento do produto e o descontrole da inflação. Deste modo, as medidas de controle do crédito, o alinhamento da taxa de câmbio, a liberação dos preços públicos e privados, a compressão salarial, a reforma financeira e tributária buscavam o controle da inflação e a futura retomada do crescimento.

\subsection{Período 1968-1973}

O período marcado pelas altas taxas de crescimento do produto também apresentou mudanças estruturais nas funções de demanda por importação e exportação. Observou-se uma quebra nas importações, que, embora indefinida, sinaliza para o aumento tanto da elasticidaderenda quanto do nível das importações. De fato, a combinação das políticas governamentais com o crescimento interno e a liquidez internacional foram favoráveis a essas modificações. Em relação às políticas econômicas, houve uma redução linear das alíquotas no Governo Castelo Branco, que passaram de um valor médio de $47 \%$ para $20 \%$, entre 1966 e 1967, embora a discriminação entre produtos produzidos ou não internamente tenha sido mantida, com os bens similares aos domésticos taxados pesadamente (LAGO, 1990, p. 274). Além disso, com o esgotamento da capacidade ociosa na indústria, as importações de máquinas e equipamentos ampliaram-se. A liquidez internacional, que permitiu financiar o crescimento com empréstimos externos, veio somar-se a essa conjuntura favorável a mudanças nos parâmetros de importação.

Em relação às exportações, as mudanças estruturais observadas também estão relacionadas à conjuntura favorável do período, que engloba a política econômica, o crescimento da economia mundial e a melhora nos termos de trocas. Também aqui foi verificada uma quebra 
indefinida, que sinaliza para o aumento tanto da elasticidade-renda quanto do nível das exportações. O crescimento da economia mundial e a melhora nos termos de troca contribuíram para o aumento tanto do volume quanto do valor das exportações, o que, em geral, tendeu a afetar mais o nível do que a elasticidade-renda da exportação. Este pareceu ser um dos caminhos para o efeito observado. Em relação à elasticidade-renda da exportação, destaca-se a política de incentivos do Governo que, embrionária em 1964, ganhou impulso entre 1967 e 1968, e, posteriormente, em 1972. Entre os instrumentos utilizados estavam isenção e crédito no pagamento de impostos de renda, IPI e ICM, créditos subsidiados à exportação, política cambial flexível com desvalorização mais frequente do cruzeiro, medidas indiretas como promoção de produtos no exterior, melhoria da infraestrutura de transporte e comercialização, e posteriormente, incentivos para o investimento em capacidade produtiva para exportação e formação de tradings (LAGO, 1990, p. 273).

Cabe ressaltar que os efeitos das quebras observadas nas funções de importação e exportação atuam em direção oposta sobre a restrição externa ao crescimento: o primeiro tem o efeito de reduzir o crescimento e o segundo ampliar. Dado o comportamento da taxa de crescimento e as variações nas magnitudes estimadas das elasticidades-renda de importação e exportação (Tabelas 2 e 3), conclui-se que o efeito da quebra na exportação superou o observado na importação para este período e, portanto, prevaleceu o efeito de abrandamento da restrição externa em termos de elasticidade. A isso soma-se uma alta liquidez e um câmbio favorável, de modo que a restrição externa explica parte do alto crescimento econômico.

\subsection{Período 1974-1982}

A opção do Governo Militar de lançar o II PND, com o objetivo de manter a taxa de crescimento e promover o ajuste necessário na estrutura de oferta do país, financiando o déficit em transações correntes e os investimentos com endividamento externo, gerou um grande debate na literatura econômica brasileira sobre as consequências dessa opção na crise que se seguiu no início dos anos 1980. Em particular, o endividamento deste período é apontado como um dos fatores principais para a crise enfrentada, e as medidas ortodoxas adotadas entre 1980 e 1982 são vistas como as responsáveis pelo ajustamento externo no período 1983-1984.

No entanto, Castro (1985) defende a tese de que foi a maturação dos investimentos do II PND que possibilitou esse resultado, e não a 
política econômica adotada no início da década e, em particular, no segundo semestre de 1982. Segundo o autor, a queda das importações e o aumento das exportações ocorreram justamente nos setores contemplados pelo II PND: metais não ferrosos, produtos químicos, papel e celulose, fertilizantes e produtos siderúrgicos.

Se de fato foi a maturação dos investimentos do II PND que alterou a estrutura produtiva do país e possibilitou a expressiva reversão do saldo comercial no período, como defende Castro (1985), então espera-se que essas mudanças, por serem estruturais, reflitam-se em valores diferentes para os parâmetros da demanda por importação e exportação.

Embora o estudo aqui realizado não permita identificar os setores em que houve mudança estrutural, uma vez que a análise é feita de forma agregada, os resultados indicam que houve uma quebra na função de demanda por exportação. Observou-se uma quebra indefinida, que sinaliza para o aumento tanto da elasticidade-renda quanto do nível das exportações, o que reduz a restrição externa ao crescimento, possibilitando ao país crescer às taxas mais altas, como mostra o Gráfico 3.

Em relação às importações, não foi verificada mudança estrutural nos parâmetros. Apesar do programa de investimento do II PND visar à substituição de impostações em setores de base, a mudança estrutural não foi captada nos parâmetros da função de importação agregada. O maior efeito desses investimentos foi captado, no agregado, pelas exportações.

\subsection{Período 1982-1989}

Já no início da década de 1980, é possível perceber uma abrupta queda na taxa de crescimento do PIB. No entanto, segundo nossos resultados, não houve, no período, uma quebra estrutural dos parâmetros da Lei de Thirlwall (elasticidades das exportações ou importações) que explicassem esse comportamento. O equilíbrio mais perverso do balanço de pagamentos nessa década pode ser explicado pelo corte no fluxo de capitais, associado a uma valorização da taxa de câmbio real. Assim, pode-se dizer que um corte no financiamento internacional, associado a uma valorização do câmbio entre 1982-1993, fez com que o equilíbrio do Balanço de Pagamentos ocorresse a uma taxa de crescimento da renda interna mais baixa.

\subsection{Período 1990-1999}

Os resultados empíricos indicam que, a partir de 1990, houve uma quebra estrutural nos parâmetros da Lei de Thirlwall com um crescimento abrupto da elasticidade-renda das importações, que levou a uma redução no crescimento do PIB. Assim, pode-se inferir que a estratégia 
de desenvolvimento dos anos 1990, através das reformas liberalizantes, reconduziu o país às suas vantagens comparativas estáticas. Conforme o esperado pelos seus idealizadores, isso gerou um crescimento significativo da produtividade. ${ }^{10}$ No entanto, por outro lado, essa "recondução" levou a economia a um padrão de especialização mais perverso do ponto de vista do equilíbrio do setor externo, ou seja, houve uma forte especialização no setor intensivo em recursos naturais em detrimento dos setores intensivos em capital e tecnologia, como pode ser visto no estudo efetuado por Moreira (1999). Mesmo dentro desses setores, houve uma especialização em segmentos de menor conteúdo tecnológico (RESENDE; ANDERSON, 1999). Essa especialização produtiva alterou a razão de elasticidades, fazendo com que o equilíbrio do setor externo passasse a ser atingido com um nível de crescimento da renda interna mais baixo a partir dos anos 1990 .

\subsection{Período 2000-2007}

Para o Governo Lula (2003-2007), observa-se um aumento na função de exportação, que poderia significar um maior aumento do produto, nos termos do modelo apresentado. Entretanto, essa quebra é mais difícil de identificar. A quebra foi considerada indefinida: pode ter sido estrutural, aumentando a elasticidade-renda das exportações e, consequentemente, aumentando a capacidade do país crescer, ou pode ser uma quebra no intercepto, o que possibilitaria um crescimento maior em um período do tempo, mas não se traduziria em uma maior capacidade de crescimento ao longo do tempo.

As elasticidades setoriais, apresentadas por Gouvêa e Lima (2009), auxiliam nessa análise. Os autores mostram que, em termos de elasticidades desagregadas, que levam em consideração as alterações na pauta exportadora, houve queda da elasticidade-renda ponderada das exportações a partir de 1995 até 2006. Isso significa que a quebra positiva que ocorreu na elasticidade de exportação a partir de 2003 não foi um movimento interno da pauta exportadora em direção a produtos com maior elasticidade-renda de exportações, e sim uma transformação no mercado internacional, que elevou a demanda por produtos usualmente exportados pelo Brasil. Nesse sentido, um fenômeno que ocorreu na década foi o aumento progressivo de exportações para a China, país que cresceu bastante no período - o que explicaria a quebra observada no intercepto - e em taxas superiores aos demais - o que explicaria a

10 Rossi Júnior e Ferreira (1999) concluem que a abertura comercial exerceu um efeito positivo sobre a produtividade do trabalho e a produtividade total dos fatores. 
quebra na declividade -, sem que tenha havido uma transformação da pauta brasileira.

\section{Considerações Finais}

Os resultados aqui apresentados mostram que, entre 1930-1980, as políticas de industrialização adotadas no Brasil permitiram, de modo geral, o abrandamento da restrição externa. Assim, por meio dos diversos ciclos do Processo de Substituição de Importação, a economia brasileira deixou de ser uma economia agrária e se tornou uma economia industrial cada vez mais dinâmica, conforme pode ser visto nos Gráficos 4 e 5, ainda que não tenha alcançado o patamar das economias avançadas.

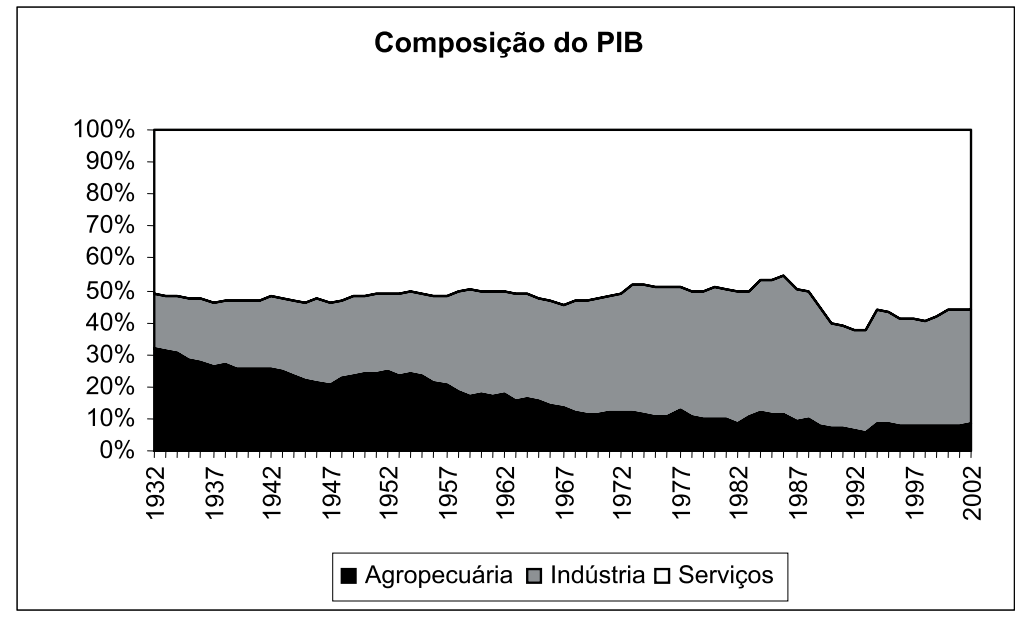

Gráfico 4 - Composição do PIB

Fonte: Elaborado pelas autoras a partir de dados do IBGE.

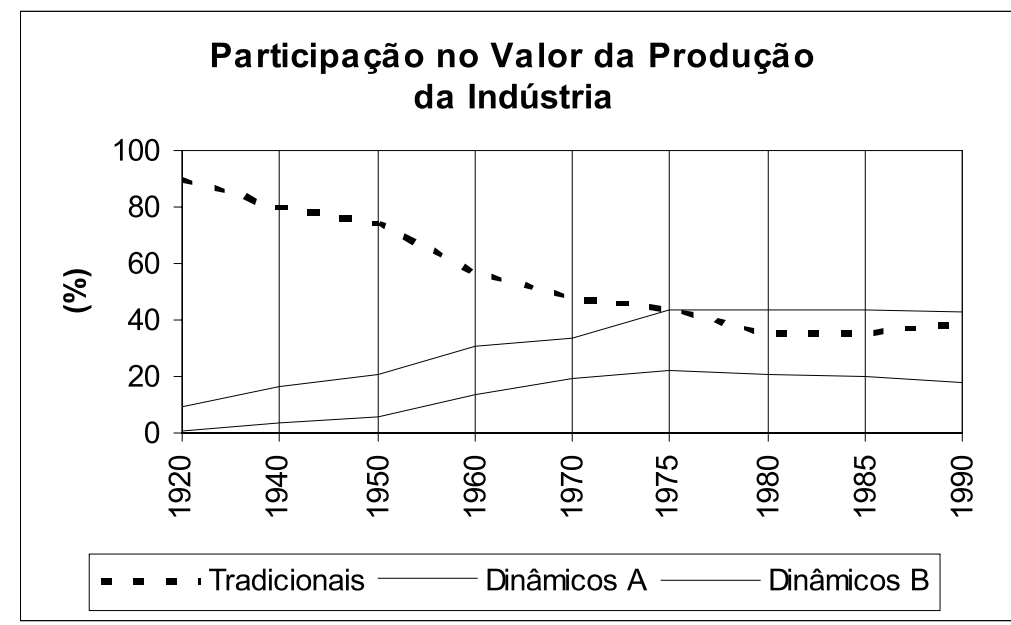

Gráfico 5 - Estrutura da Indústria

Fonte: Ipea (1998). 
Entretanto, deve-se ressaltar que o processo de industrialização brasileiro foi voltado para dentro, para substituir importações. As primeiras tentativas concretas de ampliar a exportação de produtos não tradicionais datam do período militar. Esse tipo de industrialização, em geral, tende a gerar ineficiências mais profundas do que se atuasse conjuntamente sobre importações e exportações.

Considerando essas ineficiências e não levando em conta a real existência de uma restrição externa ao crescimento brasileiro, na década de 1990, as políticas de industrialização foram ignoradas. A economia brasileira, bem como de outros países em desenvolvimento, seguiu o receituário do Consenso de Washington, promovendo a abertura comercial e financeira, a privatização de empresas estatais e alterando o foco da política econômica para o controle da inflação e do déficit público. O resultado, embora favorável no que diz respeito à estabilização dos preços na economia, foi avassalador em termos de contas externas. Além de piorar os parâmetros estruturais da restrição externa, o período foi assolado por diversas crises externas (México, Ásia, Rússia, Argentina...) que, no final da década, colocaram em xeque a sustentabilidade externa do país.

Nos anos 2000, surge outro fenômeno no mercado internacional: China. Isso colocou o Brasil na posição de escolher entre dois caminhos: seguir o exemplo chinês e reestruturar sua economia, ou aproveitar a demanda chinesa por produtos brasileiros e crescer. Diante da piora apontada nos dados desagregados e no comportamento do câmbio real, parece que o Brasil optou pelo segundo caminho. Os próximos anos refletirão os prós e os contras dessa opção.

\section{Referências}

ABREU, M. P. A ordem do progresso: cem anos de política econômica republicana 18891989. Rio de Janeiro: Campus, 1990a.

. Crise, crescimento e modernização autoritária: 1930-1945. In: ABREU, M. P. $\overline{(\mathrm{Org} .)}$ A ordem do progresso: cem anos de política econômica republicana 1889-1989. Rio de Janeiro: Campus, 1990b.

BÉRTOLA, L.; HIGACHI, H.; PORCILE, G. Balance-of-payments-constrained growth in Brazil: a test of Thirlwall's Law, 1890-1973. Journal of Post Keynesian Economics, v. 25, n. 1, p. 123-140, 2002.

CARNEIRO, D. D. Crise e esperança: 1974-1980. In: ABREU, M. P. (Org.). A ordem do progresso: cem anos de política econômica republicana 1889-1989. Rio de Janeiro: Campus, 1990. 
CARVALHO, V. R.; LIMA, G. T.; SANTOS, A. T. L. A restrição externa como fator limitante do crescimento econômico brasileiro: um teste empírico. Economia, v. 9, n. 2, p. 285-307, maio/ago. 2008.

CASTRO, A. B. Ajustamento e transformação: a economia brasileira de 1974 a 1984. In: CASTRO, A. B.; SOUZA, F. L. Economia brasileira em marcha forçada. Rio de Janeiro: Paz e Terra, 1985.

ENGLE, R. F. GRANGER, C. W. J. Cointegration and error correction: representation, estimation and testing. Econometrica, v. 55, n. 2, p. 251-276, 1987.

FERREIRA, A. A lei de crescimento de Thirlwall. 2001. Dissertação (Mestrado em Economia) - Instituto de Economia, Universidade Estadual de Campinas, Campinas, 2001.

FURTADO, C. Formação econômica do Brasil. Rio de Janeiro: Fundo de Cultura, 1959.

GIUBERTI, A. C. Instabilidade dos parâmetros das equações de importação e exportação na abordagem do crescimento sob restrição externa. São Paulo, [201-]. 25p. Trabalho não publicado.

GOUVEAA, R.; LIMA, G. Structural change, balance-of-payments constraint and economic growth: evidence from the multi-sectoral Thirlwall's law. In: ENCONTRO NACIONAL DE ECONOMIA, 37., 2009, Foz do Iguaçu. Anais... Foz do Iguaçu, 2009. Disponível em http://www.anpec.org.br/encontro_2009.htm\#trabalhos. Acesso em 28 abr. 2009.

HOLLAND, M.; VIEIRA, F.; CANUTO, O. Economic growth and the balance-of-payments constraint in Latin America. Investigación Económica, v. 43, n. 247, p. 45-74, 2004.

INSTITUTO DE PESQUISA ECONÔMICA APLICADA. A economia brasileira em perspectiva 1998. v. 2. Rio de Janeiro: IPEA, 1998.

JAYME JR., F. G. Balance-of-payments-constrained economic growth in Brazil. Revista de Economia Política, v. 23, n. 1, p. 62-84, jan. 2003.

JOHANSEN, S. Likelihood based inference in cointegrated vector auto-regressive models. Oxford: Oxford University Press, 1995.

LAGO, L. A. C. A retomada do crescimento e as distorções do "milagre". In: ABREU, P. M. (Org.). A ordem do progresso: cem anos de política econômica republicana 18891989. Rio de Janeiro: Campus, 1990.

LOPEZ, J.; CRUZ, A. Thirlwall's law and beyond: the latin american experience. Journal of Post Keynesian Economics, v. 22, n. 3, spring 2000.

MCCOMBIE, J. S. L. On the empirics of balance-of-payments-constrained growth. Journal of Post Keynesian Economics, v. 19, n. 3, p. 345-375, 1997.

MCCOMBIE, J. S. L.; THIRLWALL, A. Economic growth and the balance of payments constraint. New York: St. Martin`s Press, 1994.

MOREIRA, M. M. A indústria brasileira nos anos 90. O que já se pode dizer? In: GIAMBIAGI, F.; MOREIRA, M. M. (Org.). A economia brasileira nos anos 90. BNDES, 1999.

RESENDE, M. F. C.; ANDERSON, P. Mudanças estruturais na indústria brasileira de bens de capital. Textos para Discussão, Rio de Janeiro: IPEA, n. 420, p. 30, 1999.

ROSSI JR., J. L.; FERREIRA, P. C. Evolução da produtividade industrial brasileira e abertura comercial. Pesquisa e Planejamento Econômico, v. 29, n. 1, p. 1-36, 1999. 
SEO, B. S. Tests for structural change in cointegrated systems. Rochester: University of Rochester, 1995. Manuscript.

TAVARES, M. C. Auge e declínio do processo de substituição de importações no Brasil. In: BIELSCHOWSKY, R. (Org.). Cinquenta anos de pensamento da CEPAL. Rio de Janeiro: Record, 2000.

THIRLWALL, A. P. The balance of payments constraint as an explanation of international growth rate differences. Banca Nazionale del Lavoro Quaterly Review, v. 128, n.32 ,p. 45-53, 1979.

. The nature of economic growth: an alternative framework for understanding the performance of nations. Aldershot: Edward Elgar, 2002.

THIRLWALL, A. P.; HUSSAIN, N. H. The balance of payments constraint, capital flows and growth rate differences between developing countries. Oxford Economic Papers, v. 34, n. 3, p. 498-510, 1982.

Recebido em: 04/05/2010.

Aceito em: 15/06/2010. 